11) 131948 sta. 37,4

2. To: (Recciving Orgañízation)

Distribution

5. Proj./Prog./Dept./Div.:

15000

8. Originator Remarks:

WinCal software documentation for use by BWHC and the IAEA.

Release delayed while documents received add'1. approvals.

3. From: (Originating Organization)
Plutonium Finishing Plant Project
6. Design Authority/ Design Agent/Cog. Engr.:-
G. A. Westsik

6. Design Authority/ Design Agent/Cog, Engr.:

4. Related EDT No.:

620733

11. Receiver Remarks

11A. Design Baseline Document? [] Yes [X] No

7. Purchase Order No.:

9. Equip./Component No.:

10. System/Bldg,/Facility:

PFP Analytical Laboratory / 2736-ZB

12. Major Assm. Dwg. No.:

13. Permit/Permit Application No.:

14. Required Response Date: March 10, 1997

\begin{tabular}{|c|c|c|c|c|c|c|c|c|}
\hline 15. & & DATA & SSMI & & (F) & (G) & $(\mathrm{H})$ & (I) \\
\hline $\begin{array}{l}\text { (A) } \\
\text { ltem } \\
\text { No. }\end{array}$ & (B) Docutrent/Drawing No. & $\begin{array}{l}\text { (C) } \\
\text { Stect } \\
\text { No. }\end{array}$ & $\begin{array}{l}\text { (D) } \\
\text { Rev. } \\
\text { No. }\end{array}$ & (B) Tite or Description of Data Trass duited & $\begin{array}{c}\text { Approval } \\
\text { Desig- } \\
\text { mator }\end{array}$ & $\begin{array}{l}\text { Reason } \\
\text { for } \\
\text { Trans- } \\
\text { mital }\end{array}$ & $\begin{array}{l}\text { Oriei- } \\
\text { mator } \\
\text { Diepo- } \\
\text { sition }\end{array}$ & $\begin{array}{l}\text { Receiv- } \\
\text { er } \\
\text { Dispo- } \\
\text { sition }\end{array}$ \\
\hline 1 & HNF-SD-CP-CSCM-010 & & 0 & $\begin{array}{l}\text { Windows Calorimeter Control (WinCal)' } \\
\text { Program Computer Software } \\
\text { Configuration Mansegement Plan }\end{array}$ & $Q$ & 2 & $\bar{\cdot}$ & \\
\hline 2 & $\begin{array}{l}\text { HNF-SD-CP-CRSS-014 } \\
\text { SRS } \mathrm{kmm}\end{array}$ & & 0 & $\begin{array}{l}\text { Windows Calorimeter Control (Wincal) } \\
\text { Program Computer Software Systern } \\
\text { Requirements Specification }\end{array}$ & $Q$ & 2 & & \\
\hline 3 & $\begin{array}{r}\text { HNF-SD-CP-PDD-019 } \\
\text { Spi; }\end{array}$ & & 0 & $\begin{array}{l}\text { Windows Calorimeter Control (WinCal) } \\
\text { Program Computer Software Design } \\
\text { Description }\end{array}$ & Q & 2 & & \\
\hline 4 & HNF-SD-CP-CSUD-005 & & 0 & $\begin{array}{l}\text { Windows Calorimeter Control (WinCal) } \\
\text { Program Computer Software User } \\
\text { Documentation }\end{array}$ & Q & 2 & & \\
\hline 5 & HNF-SD-CP-TP-093 & & 0 & $\begin{array}{l}\text { Windows Calorimeter Control (WinCal) } \\
\text { Program Computer Software Test Plan }\end{array}$ & Q & 2 & & \\
\hline 6 & HNF-IP-1261 & & 0 & $\begin{array}{l}\text { Syetum Configuration Control Board } \\
\text { (SCCB) Operating Procedure }\end{array}$ & $Q$ & 2 & & . \\
\hline
\end{tabular}

16. KEY

\begin{tabular}{|c|c|c|c|c|}
\hline Approval Designator (F) & & Reason for Transmittal (O) & \multicolumn{2}{|c|}{ Disposition $(\mathrm{H}) \&(\Omega$} \\
\hline $\begin{array}{l}\text { E, S, Q, D or N/A } \\
\text { (sec WHC-CM-3-S, }\end{array}$ & $\begin{array}{l}\text { 1. Approval } \\
\text { 2. Relesere } \\
\text { 3. . }\end{array}$ & $\begin{array}{l}\text { 4. Review } \\
\text { S. Poet-Review } \\
\text { 6. Dist. (Receipt Ackrow. Required) }\end{array}$ & $\begin{array}{l}\text { 1. Approved } \\
\text { 2. Approved w/compeat } \\
\text { 3. Dispproved w/comment }\end{array}$ & 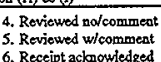 \\
\hline
\end{tabular}

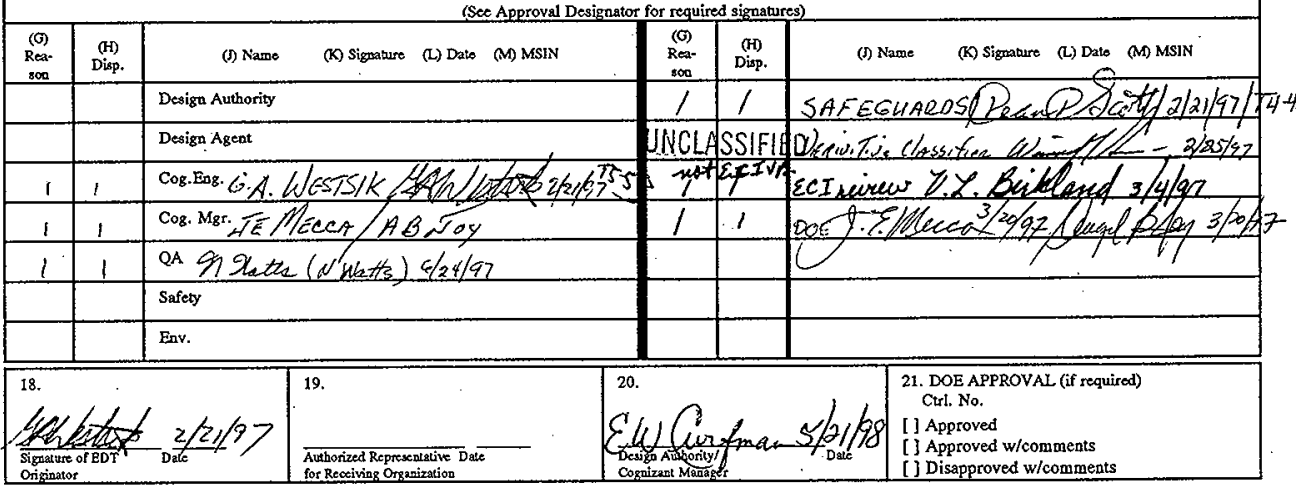

BD-7400-172-2 (05/96) GEF097

BD-7400-172-1 
Windows Calorimeter Control (WinCal) Program Computer Software

Test Plan

G. A. Westsik, BWHC, Richland, WA 99352 for the

Prepared for the Project Hanford Management Contractor for the
U.S. Department of Energy under Contract DE-ACO6-96RL 13200

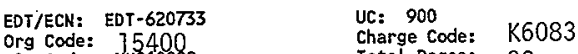

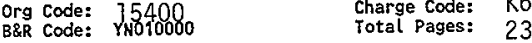

Keywords: Hincal; Calor imetry; IAEA; PFP

Trademarks:

Trademark of Microsoft Corporation Seattle, Washington.

Windows is a trademark of Microsoft Corporation, Seattle, Washington.
Windows for Workgroups 3.10 is a trademark of Microsoft Corporation, Seattle, Washington.

Abstract: This document provides the information and guidel ines necessary to conduct all the required testing of the Windows Calor imeter control (Wincal) system. The strategy and essential components for testing the hincal system Project are described in this test plan. if ic procedures for this test plan is to provide the customer
testing the specified system's functions. This material was prepared as an account of work sponsored by an agency of the United States any of their employeas assumes any legal liability or responsibility for the accuracy, completeness, or usefulness of any information, apparatus, product, or process disclosed, or represents that its use would not intringe privately owned rights. Reference to any specific commercial product, process or services name, trademark, manufacturer, or otherwise does not necessarlly constitute or inply its employees, nor its contractors acting in its behalf.

TRADEMARK DISCLAIMER. Reference herein to any specific commercial product, process, or service by trade name, trademark, manufacturer, or otherwise, does not necessarily constitute or imply its its contractors or subcontractors.

Printed in the United States of America.
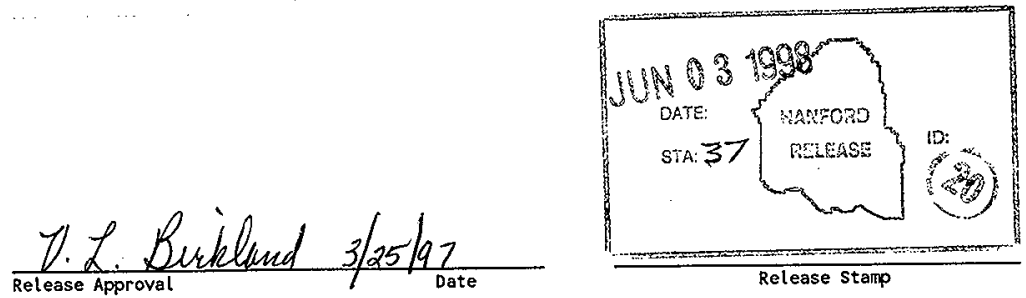

Release Stamo

Approved for Public Release

A-6400-073 (10/95) GEF321 


\section{Windows Calorimeter Control (WinCal) Program Computer Software Test Plan}

Date Published

March 1997

Prepared by

Babcock \& Wilcox Hanford Company 


\section{CONTENTS}

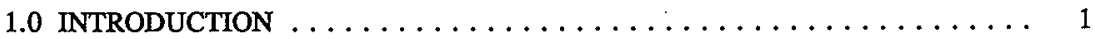

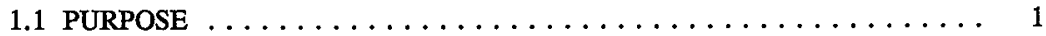

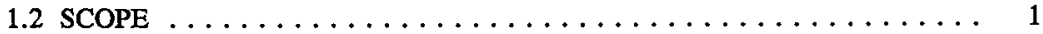

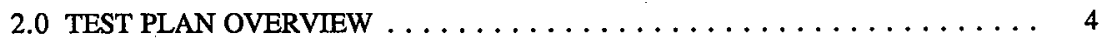

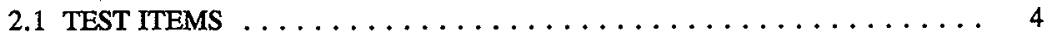

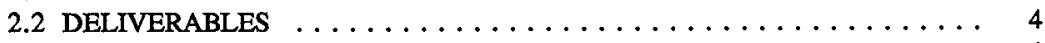

2.3 ACCEPTANCE CRTERIA $\ldots \ldots \ldots \ldots \ldots \ldots \ldots \ldots \ldots \ldots$

2.4 TEST ENVIRONMENTS $\ldots \ldots \ldots \ldots \ldots \ldots \ldots \ldots \ldots \ldots \ldots$

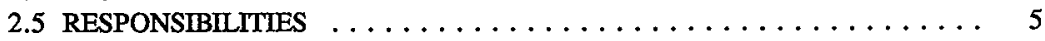

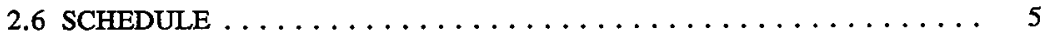

2.7 SAFETY SIGNIFICANCE $\ldots \ldots \ldots \ldots \ldots \ldots \ldots \ldots \ldots \ldots \ldots \ldots \ldots \ldots \ldots$

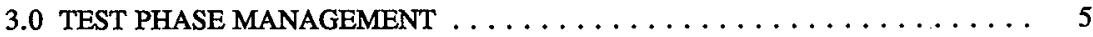

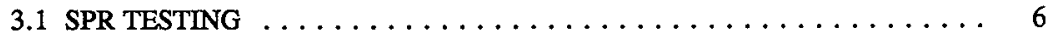

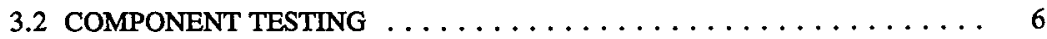

3.3 INTEGRATION TESTING $\ldots \ldots \ldots \ldots \ldots \ldots \ldots \ldots \ldots \ldots \ldots$

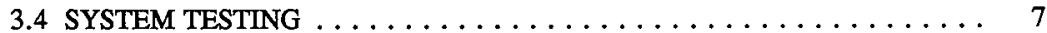

3.5 ACCEPTANCE TESTING $\ldots \ldots \ldots \ldots \ldots \ldots \ldots \ldots \ldots$

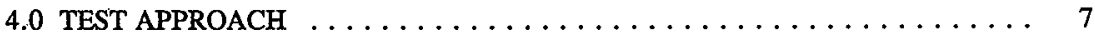

4.1 PASS/FAIL CRITERIA $\ldots \ldots \ldots \ldots \ldots \ldots \ldots \ldots \ldots \ldots$

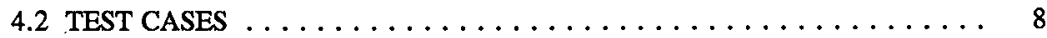

4.3 TEST DATA INPUT SPECIFICATIONS $\ldots \ldots \ldots \ldots \ldots \ldots$

4.4 WinCal SYSTEM OUTPUT SPECIFICATIONS $\ldots \ldots \ldots \ldots \ldots \ldots$

4.5 SPECIAL REQUIREMENTS $\ldots \ldots \ldots \ldots \ldots \ldots \ldots \ldots \ldots \ldots$

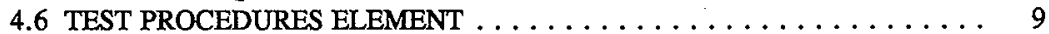

4.6.1 Procedure Results $\ldots \ldots \ldots \ldots \ldots \ldots \ldots \ldots \ldots \ldots$

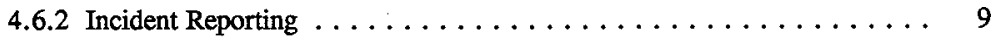

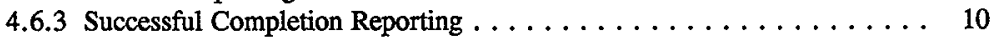

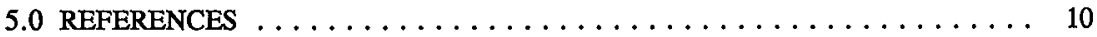

APPENDIX

A TESTING VERIFICATION $\ldots \ldots \ldots \ldots \ldots \ldots \ldots \ldots \ldots \ldots$ A-1 
HNF-SD-CP-TP-093 REV 0

\section{LIST OF TABLES}

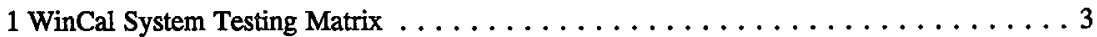

\section{LIST OF TERMS}

$\begin{array}{ll}\text { ANSI } & \text { American National Standards Institute } \\ \text { IEEE } & \text { Institute of Electrical and Electronics Engineers } \\ \text { PFP } & \text { Plutonium Finishing Plant } \\ \text { SPR } & \text { System Problem Report } \\ \text { WinCal } & \text { Windows Calorimeter Control (Program) }\end{array}$




\section{WINDOWS CALORIMETER CONTROL (WinCal) PROGRAM COMPUTER SOFTWARE TEST PLAN}

\subsection{INTRODUCTION}

This document provides the information and guidelines necessary to conduct all the required testing of the Windows Calorimeter Control (WinCal) system.

\subsection{PURPOSE}

The strategy and essential components for testing the WinCal System Project are described in this test plan. The purpose of this test plan is to provide the customer and performing organizations with specific procedures for testing the specified system's functions.

\subsection{SCOPE}

This test plan describes required testing for the WinCal system software. General testing procedures, information on test cases, and test case format are included in this document.

Testing of the WinCal system will encompass all testable aspects of the system. Each screen will be tested and each data item on that screen will be validated for content and editing criteria (if any). All reports will be produced and validated for content and format. All automated data feeds will be verified as accurately producing the desired results. The verification and validation of each test item will be compared to the requirements specified in the appropriate test procedure. See Table 1 for a detailed list of test procedures executed for each test phase.

The following general areas of WinCal system software will be tested/documented:

- Data files

- Communication with the electronic components of the calorimeter (e.g., the American National Standards Institute [ANSI]/Institute of Electrical and Electronics Engineers [IEEE] Standards 488.1, Standard Digital Interface for Programmable Instrumentation [ANSI/IEEE 1987], and 488.2, Standard Codes, Formats, Protocols, and Common Commands for Use with IEEE Standard 488.1-1987 [ANSI/IEEE 1992]) 
- User interface (test WinCal system Microsoft Windows for Workgroups Version $3.10^{1}$ functionality)

- Algorithms

- Servo power control

- End-of-run detection

- Security

- Testing of access control measures

- Testing of the integrity of the executable WinCal system software (checksum)

- System Problem Report (SPR) testing

- Installation/startup/shutdown testing.

Testing components are planned in sequence as follows:

1. SPR testing

2. Component testing

3. Integration testing

4. System testing

5. User acceptance testing.

This test plan follows the policies in WHC-CM-6-1, Standard Engineering Practices, Sections EP-4.1, "Design Verification Requirements," and EP-4.2, "Testing Practices (Validation);" WHC-CM-3-10, Software Practices, SP-3.3, "Testing," Appendix J, "System Test Documentation;" and WHC-CM-4-2, Quality Assurance Manual, QR 19.0, "Software Quality Assurance Requirements." These procedures are based on ANSI/IEEE Standard 829-1983, Test Documentation (ANSI/IEEE 1983); ANSI/IEEE Standard 1008-1987, Software Unit Testing (ANSI/IEEE 1987a); and ANSI/IEEE Standard 1012-1987, Software Verification and Validation (ANSI/IEEE 1987b).

${ }^{1}$ Microsoft Windows for Workgroups Version 3.10 is a trademark of the Microsoft Corporation, Seattle, Washington. 
Table 1. WinCal System Testing Matrix.

\begin{tabular}{|c|c|c|c|c|}
\hline SPR testing phase & $\begin{array}{c}\text { Component testing } \\
\text { phase }\end{array}$ & $\begin{array}{l}\text { Integration testing } \\
\text { phase }\end{array}$ & $\begin{array}{c}\text { System testing } \\
\text { phase }\end{array}$ & $\begin{array}{l}\text { Acceptance } \\
\text { testing phase }\end{array}$ \\
\hline $\begin{array}{l}\text { Test corrections and } \\
\text { enhancements as } \\
\text { documented in } \\
\text { system problem } \\
\text { reports }\end{array}$ & $\begin{array}{l}\text { Test items in a } \\
\text { standalone } \\
\text { environment }\end{array}$ & $\begin{array}{l}\text { Interactions among } \\
\text { components with } \\
\text { simulated data }\end{array}$ & $\begin{array}{l}\text { Program } \\
\text { operation when } \\
\text { hooked up with } \\
\text { a physical } \\
\text { calorimeter }\end{array}$ & $\begin{array}{l}\text { Operational } \\
\text { NDA testing of } \\
\text { standards }\end{array}$ \\
\hline \multirow[t]{7}{*}{$\begin{array}{l}\text { As defined per SPR } \\
\text { Test Procedure }\end{array}$} & $\begin{array}{l}\text { TPI-005, WinCal } \\
\text { Initialization/ } \\
\text { Startup Test } \\
\text { Procedure }\end{array}$ & $\begin{array}{l}\text { TPI-010, WinCal } \\
\text { Security Testing }\end{array}$ & $\begin{array}{l}\text { TPI-005, } \\
\text { WinCal } \\
\text { Initialization/ } \\
\text { Startup Test } \\
\text { Procedure }\end{array}$ & $\begin{array}{l}\text { WinCal system } \\
\text { PFP acceptance } \\
\text { test procedure }\end{array}$ \\
\hline & $\begin{array}{l}\text { TPI-006, WinCal } \\
\text { Algorithm Test } \\
\text { Procedure }\end{array}$ & $\begin{array}{l}\text { TPI-011, WinCal } \\
\text { Assay Run Test } \\
\text { Procedure }\end{array}$ & $\begin{array}{l}\text { TPI-006, } \\
\text { WinCal } \\
\text { Algorithm Test } \\
\text { Procedure }\end{array}$ & \\
\hline & $\begin{array}{l}\text { TPI-007, WinCal } \\
\text { User Interface Test } \\
\text { Procedure }\end{array}$ & & $\begin{array}{l}\text { TPI-007, } \\
\text { WinCal User } \\
\text { Interface Test } \\
\text { Procedure }\end{array}$ & \\
\hline & $\begin{array}{l}\text { TPI-009, WinCal } \\
\text { Data File Test } \\
\text { Procecture }\end{array}$ & & $\begin{array}{l}\text { TPI-008, } \\
\text { WinCal } \\
\text { Comamunication } \\
\text { with Physical } \\
\text { Calorimeter } \\
\text { Test Procedure }\end{array}$ & \\
\hline & $\begin{array}{l}\text { TPI-010, WinCal } \\
\text { Security Test } \\
\text { Procedure }\end{array}$ & & $\begin{array}{l}\text { TPI-009, } \\
\text { WinCal Data } \\
\text { File Test } \\
\text { Procedure }\end{array}$ & \\
\hline & & & $\begin{array}{l}\text { TPI-010, } \\
\text { WinCal } \\
\text { Security Test } \\
\text { Procedure }\end{array}$ & \\
\hline & & & $\begin{array}{l}\text { TPI-011, } \\
\text { WinCal Assay } \\
\text { Run Test } \\
\text { Procedure }\end{array}$ & \\
\hline
\end{tabular}

NDA = nondestructive assay.

PFP $=$ Phutonium Finishing Plant.

SPR $=$ System Problem Report.

WinCal $=$ Windows Calorimeter Control (Program). 


\subsection{TEST PLAN OVERVIEW}

\subsection{TEST ITEMS}

Testing of the WinCal system will encompass all aspects of the system. Each user interface screen will be tested and each data item on that screen will be validated in terms of content. Data files will be tested to ensure compliance with requirements. Communication with the physical calorimeter (e.g., ANSI/IEEE Standards 488.1 and 488.2 interface) will be tested. Major algorithms also will be tested. User access security will be ensured by testing the access control function designed into the WinCal system and by testing the integrity of the checksum function. System problem report solutions will be tested. WinCal system installation, startup, and shutdown functions will be tested.

All pertinent features of the system including performance, security, menu functions, update screens, and report formats will be tested and reported in the respective test documents.

\subsection{DELIVERABLES}

The deliverables associated with the testing process include the following:

- Test procedure and logs for SPR testing

- Test procedure and logs for component testing

- Test procedure and logs for integration

- Test procedure and logs for system testing

- Test procedure and logs for acceptance testing.

\subsection{ACCEPTANCE CRITERIA}

Successful completion of the user acceptance test will constitute final customer acceptance of the WinCal system computer software.

At the conclusion of the Acceptance Testing phase, the test results are documented and reviewed to ensure that requirements have been met. The acceptance testing report will then be prepared by Babcock and Wilcox Hanford Company and will include the status of anomalies found and corrected during testing.

\subsection{TEST ENVIRONMENTS}

Testing relative to ANSI/IEEE Standards 488.1 and 488.2 communications, time critical testing, servo control, and end-of-run detection will be conducted on the user's installed equipment (i.e., computer and calorimeter[s]) on which the system will run in the production 
environment. Any testing not requiring the Plutonium Finishing Plant (PFP) system will be conducted on similarly configured systems (e.g., computer hardware and software but not on ANSI/IEEE Standards 488.1 and 488.2 or calorimeter hardware).

\subsection{RESPONSIBILITIES}

The success of the testing process relies heavily on user involvement throughout all phases of test definition, development, and execution. The personnel involved need to have detailed knowledge of the system requirements, as well as some working knowledge of the machines being used and the software required for the system.

Babcock and Wilcox Hanford Company PFP Analytical Labs management will monitor the final stages of acceptance testing, review the test results, and approve the readiness of the WinCal system for installation.

\subsection{SCHEDULE}

The schedule for testing and acceptance of the WinCal system is included as part of the overall WinCal project schedule in the WinCal Statement of Work and Project Management Plan.

\subsection{SAFETY SIGNIFICANCE}

The WinCal system is not considered a safety-significant system. It is assumed that a WinCal system failure would not jeopardize lives, facilities, or the environment. Heatproducing standards are run periodically to ensure that WinCal system results are accurate. Erroneous WinCal system results are assumed to not result in significant dollar losses.

\subsection{TEST PHASE MANAGEMENT}

For purposes of configuration management and control during testing, this test plan for the WinCal system is separated into five major phases as identified in Table 1. Each test phase is managed as a release with a unique WinCal system version number used for configuration management. Within each test phase and release, problems that are identified will be recorded on the SPR form. The release will then be put back into the development environment. The problems identified in the SPRs will be corrected. When all SPRs have been completed, the release will be incremented with an alpha character and installed back in the test environment. The test phase will be repeated until successful. 
Certain test cases for the WinCal system rely on nonrepeatable inputs to execute. The test procedure steps themselves will be viewed as test cases for most WinCal system testing.

\subsection{SPR TESTING}

The SPR Testing phase is conducted by the software engineers. The SPR testing involves examination of SPR requirements and development of the software to resolve the problem identified for verification that the results satisfy the problem requirements. As packages of SPRs are implemented, tested, and approved by the user, they are incorporated into a release awaiting further testing.

\subsection{COMPONENT TESTING}

The Component Testing phase is conducted by the software engineers and system users. Component testing is to be performed in a standalone environment; testing does not need to be performed on the WinCal computer system at the PFP. Testing can be performed on similarly configured computers (i.e., computers with the same configuration as the PFP WinCal system computer) without interfacing with the PFP calorimeters. Screens (e.g., controls, fields, menu items, accelerator keys, and data validation); data files (e.g., one-second data collection, history, and .INI files); algorithms; and installation, startup, shutdown, and security passwords are tested.

As individual modules of the system are approved by the user, they are collected into a candidate set of code modules awaiting integrated testing. This means configuration control is in effect for the modules and test data.

\subsection{INTEGRATION TESTING}

The Integration Testing phase is conducted by the software engineers with participation by the system users. Integration Testing involves testing the interfaces among the individual software programs using simulated data to ensure that the modules are sending and receiving data in accordance with the design specifications. Any output consisting of hard copy and online reports, at the discretion of the software engineers and system users, will be reviewed to ensure correct format and content.

Integration Testing will be performed in a standalone environment; testing does not need to be performed on the WinCal computer system at the PFP. Testing can be performed on similarly configured computers (i.e., computers with the same configuration as the PFP WinCal system computer) without having to be interfaced with the PFP calorimeters. 


\subsection{SYSTEM TESTING}

The System Testing phase tests the final production environment, including not only the automated portions but also any user interface elements. These elements include user personnel preparing data input to the automated system and use of the output. The system test is the checkpoint to verify that the system performs correctly, and it should eliminate system or design errors. System testing for the WinCal system is viewed as the Readiness Review to ensure that WinCal system software is ready for user acceptance testing.

During system testing, prospective program operation is tested by interfacing with at least one physical calorimeter. Communications with the physical calorimeter, one heat standard, data screens, and installation, startup, and shutdowns are tested. Configuration control will be in effect during system testing.

\subsection{ACCEPTANCE TESTING}

The Acceptance Testing phase is performed to demonstrate that fabrication, assembly, installation, and implementation requirements have been met as defined in HNF-SD-CP-CSRS-014, Windows Calorimeter Control (WinCal) Program Computer Software System Requirements Specification, and HNF-SD-CP-SDD-019, Windows Calorimeter Control (WinCal) Program Computer Software Design Description. This will be accomplished by system users with assistance from software engineers.

The success of acceptance testing is mainly determined by the successful analysis of a range of heat-generating standards (plutonium) already characterized at the PFP laboratory. The customer will determine the specific standards and materials to be run and will perform this part of acceptance testing.

The hardware and software are tested to ensure they are operating in accordance with design specifications. Acceptance testing is the user's formal testing and certification of the completed system. Acceptance testing also establishes a baseline for the WinCal system and its components.

\subsection{TEST APPROACH}

Test procedures will be developed for the areas described in Section 1.2 of this test plan. Test logs, with the disposition of any anomalies discovered during testing, will be documented. Test logs are integral to the test procedures and are not separate documents. Pass/fail notes will be entered into the test procedures. 
At the discretion of the testers, testing may be suspended. Resumption of testing will begin at the point that testing was suspended. Any software that was changed and had already passed testing will be retested and approved.

\subsection{PASS/FAIL CRITERIA}

Acceptance criteria state the conditions that must be satisfied by the system or products before the user formally accepts the system. If a test procedure achieves all of its requirements, it is considered a PASS. If a test procedure does not achieve all of its requirements, it is considered a FAIL and must be corrected and retested. If the test produces a result that is not desirable by the user or the user's management and it meets the requirements detailed in the test procedure, a decision must be made to either change the requirement and retest or PASS the test.

\subsection{TEST CASES}

All test procedures will have test cases developed for them and will be uniquely identified where applicable.

\subsection{TEST DATA INPUT SPECIFICATIONS}

Test data will be developed or provided to thoroughly test all areas of the WinCal system. Where possible, this data will be identified in such a way that the correct outcome is known in advance. Effectiveness of the data will be ensured through joint participation by user personnel. Transactions that are specifically designed to check internal controls and decision logic will be included. Examples of invalid, abnormal, and incomplete transactions will be included in the test data. These transactions will be checked to verify that they work properly and give the appropriate responses to improper conditions.

\subsection{WinCal SYSTEM OUTPUT SPECIFICATIONS}

All elements within the WinCal system will meet or exceed the following requirements, as stated in the test procedures.

- File data will be of the documented length and type.

- Calculated fields will function properly.

- Screens will be formatted and display/update data as documented. 
- Reports will present data in a manner consistent with HNF-SD-CP-CSRS-014 and HNE-SD-CP-SDD-019.

- Security/access to data, screens, and reports will meet design specifications. Unauthorized entry into the system will be restricted in accordance with established user privileges.

\subsection{SPECIAL REQUIREMENTS}

Any special characteristics or configurations of the hardware or software needed to execute this test case will be included in each test procedure. Special constraints on the test procedures for test cases (e.g., special setup, increased number of users, operator intervention, output.determination procedures, special wrap-up) will be specified in the test procedure.

\subsection{TEST PROCEDURES ELEMENT}

Test procedures will detail the process of confirming the individual test requirements. Actual test cases will be developed and documented in the test procedure. Results of the testing process will be documented in each test procedure.

Visually observable results (error messages generated, aborts, and requests for operator action) and notes on the successful execution of the test will be recorded in the test procedure. Test problems/deficiencies/defects need to be noted in the test procedure at the specific step where the problem occurred.

\subsubsection{Procedure Results}

Steps for executing a set of test cases or, more generally, the steps used to analyze a software requirement for evaluating a set of features, will be specified.

\subsubsection{Incident Reporting}

Test incidents will be reported using the SPR. Required information on the SPR and/or test procedure is as follows:

- Expected results

- Actual results

- Date and time

- Procedures/numbers

- Tester 
- Witness if required

- Procedure step.

\subsubsection{Successful Completion Reporting}

The success of the test procedure will be documented in the test procedure. Information to be recorded is as follows:

- Expected resuits

- Actual results

- Date/time

- Tester

- Witness if required

- Approval signature.

\subsection{REFERENCES}

ANSI/IEEE, 1983, Test Documentation, ANSI/IEEE Standard 829-1983, American National Standards Institute/Institute of Electrical and Electronics Engineers, New York, New York.

ANSI/IEEE, 1987 (R94), Standard Digital Interface for Programmable Instrumentation, ANSL/IEEE Standard 488.1, American National Standards Institute/Institute of Electrical and Electronics Engineers, New York, New York.

ANSI/IEEE, 1987a, Software Unit Testing, ANSI/IEEE Standard 1008-1987, American National Standards Institute/Institute of Electrical and Electronics Engineers, New York, New York.

ANSI/IEEE, 1987b, Software Verification and Validation, ANSI/IEEE Standard 1012-1987, American National Standards Institute/Institute of Electrical and Electronics Engineers, New York, New York.

ANSI/IEEE, 1992, Standard Codes, Formats, Protocols, and Common Commands for Use with IEEE Standard 488.1-1987, ANSI/IEEE Standard 488.2, American National Standards Institute/Institute of Electrical and Electronics Engineers, New York, New York.

HNF-SD-CP-CSRS-014 WinCal Computer Software System Requirements Specification, Rev. 0, Fluor Daniel Hanford Inc., Richland, Washington. 
HNF-SD-CP-SDD-019, WinCal Computer Software Design Description, Rev. 0, Fluor Daniel Hanford Inc., Richland, Washington.

WHC-CM-3-10, Software Practices, Westinghouse Hanford Company, Richland, Washington.

WHC-CM-4-2, Quality Assurance Manual, Westinghouse Hanford Company, Richland, Washington.

WHC-CM-6-1, Standard Engineering Practices, Westinghouse Hanford Company, Richland, Washington. 
HNF-SD-CP-TP-093 REV 0

This page intentionally left blank. 
HNF-SD-CP-TP-093 REV 0

APPENDIX A

TESTING VERIFICATION

A-1 
HNF-SD-CP-TP-093 REV 0

This page intentionally left blank.

A-2 


\section{SOFTWARE PROBLEM REPORTING \\ TEST PHASE \\ VERIFICATION SHEET}

This form provides a record of verification that the relevant test procedures associated with each of the software problem reports for each of the Windows Calorimeter Control (WinCal) Program development phases have been completed. Any exceptions that may have been identified during testing of those procedures have been corrected and retested successfully. The verification sheet for each test procedure and for the test phase has been completed and signed by the appropriate parties.

George Westsik, BWHC / PFP

Date

Richard A. Hamilton, BWHC / PFP

Date

Dean Scott, B\&W Protec

Date

Nichoploi F. Pertzborn , LMSI

Date 


\section{COMPONENT TEST PHASE VERIFICATION SHEET}

The following test procedures are required to provide verification that the Windows Calorimeter Control (WinCal) Program software meets the requirements of Component Testing as identified in the Windows Calorimeter Control (WinCal) Program Computer Software Test Plan (HNF-SD-CP-TP-093.)

- TPI-005, WinCal Initialization/Startup Test Procedures

- TPI-006, WinCal Algorithm Test Procedure

- TPI-007, WinCal User Interface Test Procedure

- TPI-009, WinCal Data File Test Procedure

- TPI-010, WinCal Security Test Procedure

This form provides a record of verification that the relevant test procedures have been completed. Any exceptions that may have been identified during testing of these procedures have been corrected and retested successfully. The verification sheet for each test procedure and for the test phase has been completed and signed by the appropriate parties. 


\section{INTEGRATION TEST PHASE VERIFICATION SHEET}

The following test procedures are required to provide verification that the Windows Calorimeter Control (WinCal) Program software meets the requirements of Integration Testing as identified in the Windows Calorimeter Control (WinCal) Program Computer Software Test Plan (HNF-SD-CP-TP-093).

- TPI-010, WinCal Security Test Procedure

- TPI-011, WinCal Assay Run Test Procedure

This form provides a record of verification that the relevant test procedures have been completed. Any exceptions that may have been identified during testing of these procedures have been corrected and retested successfully. The verification sheet for each test procedure and for the test phase has been completed and signed by the appropriate parties.

George Westsik, BWHC / PFP

Richard A. Hamilton, BWHC / PFP

Larry McRae, B\&W Protec

Nichoploi F. Pertzborn , LMSI

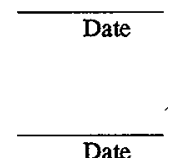

Date

Date

Date 


\section{SYSTEM TEST PHASE VERIFICATION SHEET}

The following test procedures are required to provide verification that the Windows Calorimeter Control (WinCal) Program software meets the requirements of System Testing as identified in the Windows Calorimeter Control (WinCal) Program Computer Software Test Plan (HNF-SD-CP-TP-093).

- TPI-005, WinCal Initialization/Startup Test Procedures

- TPI-006, WinCal Algorithm Test Procedure

- TPI-007, WinCal User Interface Test Procedure

- TPI-008, WinCal Communication with Physical Calorimeter Test Procedure

- TPI-009, WinCal Data File Test Procedure

- TPI-010, WinCal Security Test Procedure

- TPI-011, WinCal Assay Run Test Procedure

This form provides a record of verification that the relevant test procedures have been completed. Any exceptions that may have been identified during testing of these procedures have been corrected and retested successfully. The verification sheet for each test procedure and for the test phase has been completed and signed by the appropriate parties. 


\section{ACCEPTANCE TEST PHASE VERIFICATION SHEET}

The following test procedure is required to provide verification that the Windows Calorimeter Control (WinCal) Program software meets the requirements of Acceptance Testing as identified in the Windows Calorimeter Control (WinCal) Program Computer Software Test Plan (HNF-SD-CP-TP-093).

- WinCal BWHC/PFP Acceptance Test Procedure

This form provides a record of verification that the relevant test procedures have been completed. Any exceptions that may have been identified during testing of these procedures have been corrected and retested successfully. The verification sheet for each test procedure and for the test phase has been completed and signed by the appropriate parties. 
HNF-SD-CP-TP-093 REV 0

This page intentionally left blank.

A-8 


\section{DISTRIBUTION SHEET}

\begin{tabular}{|c|c|c|c|c|c|}
\hline \multirow{2}{*}{$\begin{array}{l}\text { To } \\
\text { Distribution }\end{array}$} & \multirow{2}{*}{\multicolumn{3}{|c|}{$\begin{array}{l}\text { From } \\
\text { Lockheed Martin Services, } \\
\text { Inc., Systems Development and } \\
\text { Integration } \\
\end{array}$}} & \multicolumn{2}{|l|}{ Page 1 of 1} \\
\hline & & & & \multicolumn{2}{|l|}{ Date $6 / 2 / 98$} \\
\hline \multicolumn{4}{|l|}{ Project Title $/$ Work Order } & \multicolumn{2}{|c|}{ EDT No. 620733} \\
\hline $\begin{array}{l}\text { Revision 0, Windows Calorimeter } \\
\text { Computer Software Documentation }\end{array}$ & \multicolumn{3}{|c|}{ Control (WinCal) Program } & ECN No. & \\
\hline Name & MSIN & $\begin{array}{c}\text { Text } \\
\text { With All } \\
\text { Attach. }\end{array}$ & Text Only & $\begin{array}{l}\text { Attach./ } \\
\text { Appendix } \\
\text { Only }\end{array}$ & $\begin{array}{l}\text { EDT/ECN } \\
\text { Only }\end{array}$ \\
\hline
\end{tabular}

W. D. Bartlett

F. R. Crawford

R. A. Hamilton

A. B. Joy

K. M. Mathison

D. D. Scott

G. A. Westsik Central Files ESTSC
(6 copies)

(2 copies)
T5-50

T5-50

T5-06

R3-79

S2-12

T4-40

T5-53

B1-07

H6-08 $x$
$\chi$
$\chi$
$\chi$
$\chi$
$\chi$
$\chi$
$\chi$
$\chi$ 